\title{
Effect of hypotensive hypovolemia and thoracic epidural anesthesia on plasma pro-atrial natriuretic peptide to indicate deviations in central blood volume in pigs: a blinded, randomized controlled trial
}

This article was published in the following Dove Press journal: Local and Regional Anesthesia

\author{
Rune B Strandby' \\ Rikard Ambrus' \\ Michael P Achiam' \\ Amalie Henriksen' \\ Jens P Goetze ${ }^{2}$ \\ Niels H Secher ${ }^{3}$ \\ Lars B Svendsen' \\ 'Department of Surgical \\ Gastroenterology, ${ }^{2}$ Department of \\ Clinical Biochemistry, ${ }^{3}$ Department of \\ Anesthesiology, Rigshospitalet, University \\ of Copenhagen, Copenhagen, Denmark
}

Correspondence: Rune B Strandby Department of Surgical Gastroenterology, University of Copenhagen, Inge Lehmanns

Vej 7, Copenhagen DK-2100, Denmark

$\mathrm{Tel}+452245$ 1331

Email runestrandby@hotmail.com
Purpose: Changes in plasma pro-atrial natriuretic peptide (proANP) may indicate deviations in the central blood volume (CBV). We evaluated the plasma proANP response to hypotensive hypovolemia under the influence of thoracic epidural anesthesia (TEA) in pigs. We hypothesized that plasma proANP would decrease in response to hypotensive hypovolemia and that TEA would aggravate the proANP response, reflecting a further decrease in CBV.

Design: Randomized, blinded, controlled trial.

Setting: A university-affiliated experimental facility.

Participants: Twenty pigs randomized to administration of saline (placebo) or bupivacaine with morphine (TEA) in the epidural space at Th8-Th10.

Interventions: Relative hypovolemia was established by an inflatable Foley catheter positioned in the inferior caval vein just below the heart (caval obstruction), and hemorrhageinduced hypovolemia was by withdrawal of blood from the femoral artery, both aiming at a mean arterial pressure (MAP) of 50-60 $\mathrm{mmHg}$. Hemodynamic variables and plasma proANP were determined before and after the interventions.

Results: Caval obstruction and withdrawal of blood reduced MAP to $50-60 \mathrm{mmHg}$. Accordingly, cardiac output, central venous pressure, and mixed venous oxygen saturation decreased $(p<0.05)$. Yet, plasma proANP was stable after both caval obstruction (TEA: 72 [63-78] to $80 \mathrm{pmol} / \mathrm{L}$ [72-85], $p=0.09$ and placebo: 64 [58-76] to $69 \mathrm{pmol} / \mathrm{L}$ [57-81], $p=0.06$ ) and withdrawal of blood (TEA: 74 [73-83] to $79 \mathrm{pmol} / \mathrm{L}$ [77-87], $p=0.07$ and placebo: 64 [56-77] to $67 \mathrm{pmol} / \mathrm{L}[58-78], p=0.15)$.

Conclusion: Plasma proANP was stable in response to relative and hemorrhage-induced hypovolemia to a MAP of 50-60 mmHg, and the response was independent of TEA. The findings suggest that alterations in plasma proANP do not follow deviations in CBV during hypotensive hypovolemia in pigs.

Keywords: atrial natriuretic factor, hemorrhage, hypovolemia, epidural anesthesia, pigs, hypotension

\section{Introduction}

Maintenance of the central blood volume (CBV) during surgery by fluid and vasopressors is important for compensating vasodilation induced by both general and regional anesthesia and for a potential blood loss. ${ }^{1,2}$ Yet, evaluation of CBV is 
challenging because monitoring of hemodynamic variables such as blood pressure and heart rate (HR) is not a reliable determinant of the circulating blood volume in response to fluid administration. ${ }^{3,4}$

Atrial natriuretic peptide (ANP) is produced by the atrial myocytes, and the main stimulus for its release is atrial wall distention ${ }^{5,6}$ eliciting diuresis and vasorelaxation of importance for blood volume regulation. ${ }^{7,8}$ Accordingly, alteration in plasma ANP reflects changes in CBV as determined by scintigraphy and thoracic electrical impedance..$^{9-12}$ Thus, plasma ANP increases in response to blood volume expansion ${ }^{13}$ or exercise $^{14}$ and, conversely, decreases when preload to the heart is reduced by head-up tilt $^{12}$ and lower body negative pressure. ${ }^{15}$ Furthermore, perioperative monitoring of plasma ANP may be feasible to evaluate CBV during surgery. Plasma proANP, a stable variant of ANP, has been applied to evaluate perioperative fluid balance during esophagectomy ${ }^{16}$ and cystectomy, ${ }^{17}$ and an inverse relation to the perioperative blood loss is reported. ${ }^{17}$

This study evaluated the plasma proANP response to the reduction in CBV in pigs. To evaluate both relative and hemorrhage-induced hypovolemia, caval obstruction of venous flow was induced, or withdrawal of blood was carried out. The pigs were randomized to thoracic epidural anesthesia (TEA) or epidural injection of saline (placebo) applied during the interventions. It was considered that by the TEA-induced block of sympathetic influence on vascular tone, the ability to preserve $\mathrm{CBV}$ by vasoconstriction during relative or hemorrhage-induced hypovolemia would be affected. ${ }^{2,18}$ We hypothesized that plasma proANP would decrease in response to both caval obstruction of venous blood to the heart as to hemorrhage and that the reduction in plasma proANP would be aggravated by TEA.

\section{Materials and methods Study design}

The study is a blinded, randomized, controlled trial aiming at evaluating the impact of hypotensive hypovolemia on plasma proANP during the influence of TEA/placebo as a primary end point with hemodynamic variables as secondary end points. The study was approved by the local Animal Experiments Inspectorate (protocol number 201415-0201-00385 approved on October 30, 2014) in accordance with the national and the European Union legislation. The manuscript adheres to the applicable ARRIVE guidelines.

\section{Randomization}

The pigs were allocated to TEA or placebo (www.random. org) with numbered envelopes padded by non-transparent paper. A veterinarian was responsible for the envelopes and attested adherence to the randomization protocol and initiated dispensation of TEA/placebo while the principal investigator was blinded to the administration during the study.

\section{Instrumentation of animals}

Twenty female pigs (Danish Landrace/Yorkshire, 10-12 weeks of age) were housed in pairs and acclimatized under standardized room temperature, humidity, and light-dark cycles for two weeks with feeding provided until $12 \mathrm{hRS}$ before anesthesia.

In the morning of the experiment, the pigs were sedated by intramuscular benzodiazepine and tiletamine $(5 \mathrm{mg} / \mathrm{kg}$, Zoletil Vet., Virbac, Kolding, DK) and anesthetized by intravenous propofol $(15 \mathrm{mg} / \mathrm{kg} / \mathrm{hR})$ and fentanyl $(5 \mu \mathrm{g} /$ $\mathrm{kg} / \mathrm{hR}$ ). The body was kept warm by foil blankets and ventilation was maintained by an endotracheal tube and adjusted to an end-tidal carbon dioxide tension of 4.5-6.5 $\mathrm{kPa}$ and oxygen tension of $11-15 \mathrm{kPa}$ by $25-45 \%$ oxygen. The CBV was supported by lactated Ringer's solution (5 $\mathrm{mL} / \mathrm{kg} / \mathrm{hR}$ ) administered continuously during the experiment. A catheter (Epidural Minipack System 1, Smiths Medical, Hranice, CZ) was placed at the 8th-9th or 9th10th thoracic intervertebral space and its position verified by $\mathrm{x}$-ray after injection of $2 \mathrm{~mL}$ contrast. A pulmonary artery catheter was inserted via the right external jugular vein for determination of cardiac output (CO) by thermodilution (Vigilance Monitor, Edwards Life Sciences, Irvine, CA, USA). Catheters were placed in the femoral arteries, the right for monitoring blood pressure and the left for withdrawal of blood. To reduce venous flow to the heart (relative hypovolemia), hypotension was induced by caval vein obstruction. The left femoral vein was identified by dissection, and a Foley catheter ( 8 Fr x $60 \mathrm{~cm}$, MILA international, Florence, KY, USA) advanced to the right atrium through an introducer (12 Fr, Peel-Away ${ }^{\mathbb{R}}$ Introducer, Cook Medical, Bloomington, IN, USA). The catheter was inflated and withdrawn until there was an abrupt decrease in systolic blood pressure (SBP $>20$ $\mathrm{mmHg}$ ), and the tip of the catheter was then considered positioned at the inlet of the right atrium. Next, the balloon was deflated and withdrawn $2.5 \mathrm{~cm}$ for a position just below the heart without obstructing the hepatic vein. 
Hemodynamic variables were recorded by Powerlab 16/ 35 (AD Instruments, Dunedin, NZ) including CO, mean arterial pressure (MAP), HR, and central venous pressure (CVP). Systemic vascular resistance (SVR) was: $S V R=\frac{80 \mathrm{x}(\mathrm{MAP}-\mathrm{CVP})}{\mathrm{CO}}$. Also, arterial blood samples for plasma proANP were obtained.

Hemodynamic variables were measured and blood for determination of plasma proANP withdrawn before and after the interventions. Also, a blood sample for mixed venous oxygen saturation $\left(\mathrm{SvO}_{2}\right)$ was obtained before and after withdrawal of blood reflecting that a volume deficit by approximately $100 \mathrm{~mL}$ corresponds to a decrease in $\mathrm{SvO}_{2}$ by $1 \%$ in adult humans. ${ }^{1}$ The blood volume of the pigs was estimated as $8 \%$ of body weight. ${ }^{19}$

\section{TEA dosage}

To rule out spinal or intravascular placement of the epidural catheter injection of $2 \mathrm{~mL}$ lidocaine/adrenaline was administered (20 mg/5 $\mu \mathrm{g} / \mathrm{mL}$, SAD, Amgros I/S, DK). Then, TEA was established by a bolus of $2 \mathrm{~mL}$ bupivacaine $(5 \mathrm{mg} / \mathrm{mL}, \mathrm{SAD})$ followed by infusion $(2 \mathrm{~mL} / \mathrm{hR})$ of bupivacaine/morphine $(2.5 \mathrm{mg} / 50 \mu \mathrm{g} / \mathrm{mL}, \mathrm{SAD})$ through the remaining procedure. The placebo group was administered saline $(0.9 \%)$ in the epidural catheter in similar amounts as in the TEA group.

\section{Experimental procedure}

The animals were placed in a supine position during the experimental procedure and baseline recordings were obtained prior to activation of TEA. After epidural injections of local anesthesia or placebo, cardiovascular variables and blood samples were obtained after 15 and 30 mins. The balloon of the Foley catheter was then inflated to obstruct venous flow to the heart aiming at a 50-60 mmHg MAP with evaluation after 5 and 15 mins. After the balloon was deflated and MAP normalized, the measurements were repeated after 5 and 15 mins. Lastly, withdrawal of blood until a MAP of 50-60 $\mathrm{mmHg}$ was carried out and measurements were repeated after 5 and 15 mins. After the study, the animals were euthanized by intravenous pentobarbital (at least $100 \mathrm{mg} / \mathrm{kg}$ ) while anesthetized.

\section{Plasma proANP}

Plasma proANP (amino-acids 53-90), rather than ANP (amino acids 98-128), was determined because ANP has a short half-life in plasma. ${ }^{20-22}$ Also, plasma proANP may be a more precise plasma marker because little proteolytic degradation is assumed to occur at the mid-region of the prohormone, ${ }^{22}$ and it is released in equimolar amounts as ANP. $^{23}$ Arterial blood samples for plasma proANP were obtained in EDTA tubes and centrifuged at $3,000 \mathrm{rpm}$ at $4{ }^{\circ} \mathrm{C}$ for 10 mins and stored at $-80^{\circ} \mathrm{C}$ until analysis. Plasma proANP was determined using an automated method from Thermo-Fisher (the Kryptor Plus platform), and the sandwich immunoassay was validated with excellent performance. ${ }^{20,24}$

\section{Statistical analysis}

Statistical analysis was by SPSS (IBM SPSS Statistics for Windows, Version 22.0. Armonk, NY, USA) and graphs were constructed by GraphPad Prism Software (Version 7.0, San Diego, CA, USA). Data were tested for normality using the Shapiro-Wilk test, and due to a non-normal distribution, non-parametric statistic was chosen. For repeated measurements within groups, Friedman's test with Bonferroni correction was applied (primary and secondary outcomes). To test for differences between groups at a single time point, MannWhitney's $U$-test was applied for continuous variables and the $X^{2}$-test or Fisher's exact test for dichotomous variables. A twosided $p$-value $\leq 0.05$ was considered statistically significant. The hemodynamic variables are presented as medians with interquartile range and represent recordings over $30 \mathrm{~s}$. A decrease in plasma ANP by at least $24 \%$ (SD $1.6 \mathrm{pmol} / \mathrm{L}$ ) is reported during hypotensive hypovolemia in man, ${ }^{12}$ and a power calculation (power: 0.8 and $\alpha$-level: 0.05 ) predicted that eight pigs were required to detect a difference in any of the groups. To account for possible exclusion, 20 pigs were studied.

\section{Results}

For two animals, the epidural catheter was not placed correctly as evaluated by x-ray. Thus, the study included eight pigs provided TEA, and 10 pigs were administered saline in the epidural space. The body weight was similar (41 (39-43) [TEA] vs $42 \mathrm{~kg}$ (41-43) [placebo], $p=0.24)$, and hemodynamic variables and plasma proANP were also not significantly different between the groups at baseline (Figure 1).

\section{TEA}

After administration of saline to the epidural space (placebo group), no hemodynamic changes were observed. However, activation of TEA increased HR $(p=0.03)$ at a stable CO $(p=0.5)$, while MAP $(p=0.01)$ decreased and thus SVR was reduced $(p<0.01)$ (Figure 1). 


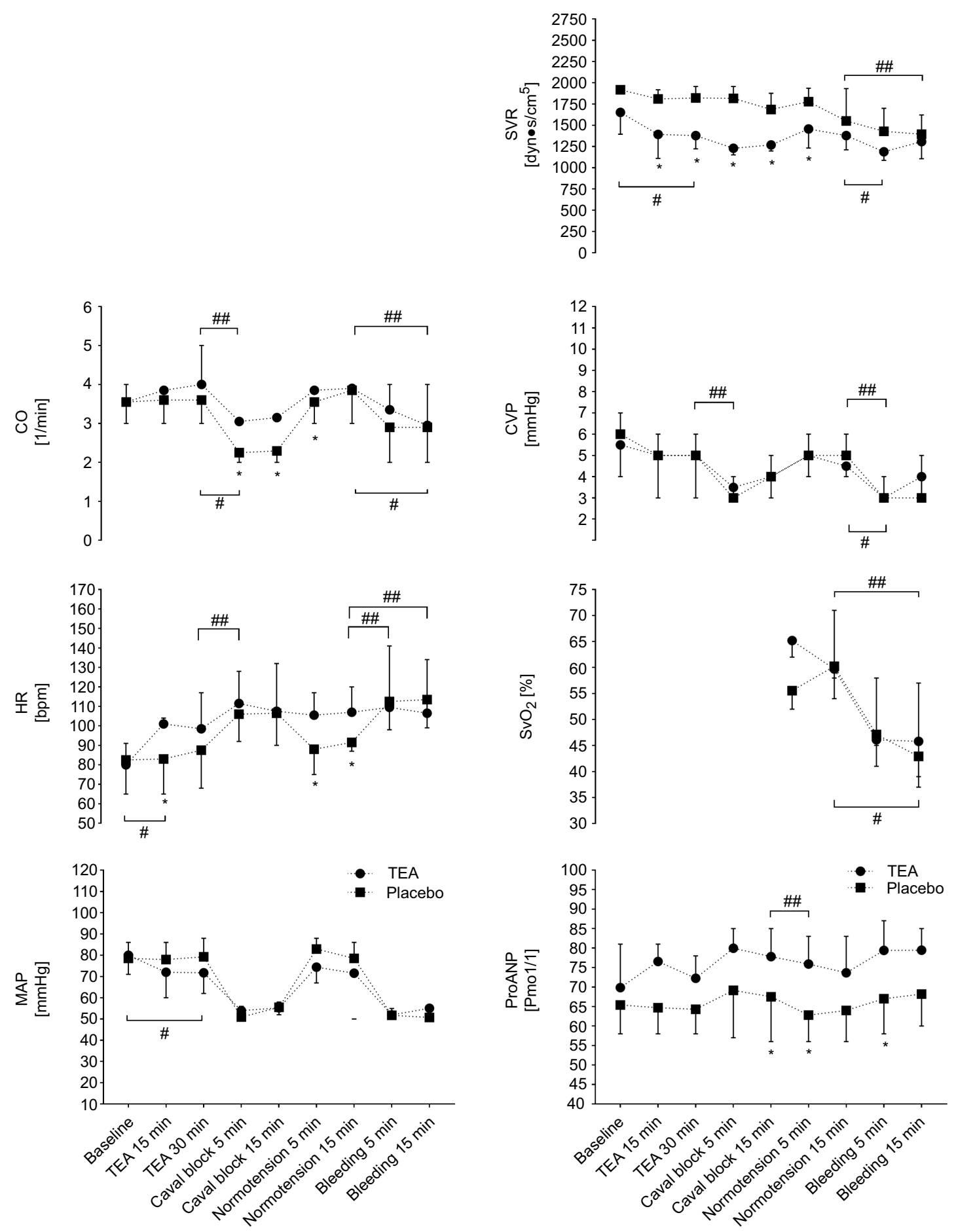

Figure I Plasma pro-atrial natriuretic peptide (proANP) and hemodynamic variables during induced hypotension in pigs by caval blockade and withdrawal of blood, respectively. Values are medians with interquartile range. Change during the marked period in the thoracic epidural anesthesia (TEA), \#, and the placebo-groups, \#\# by Friedman's test, $p<0.05$. *Significant difference between groups at a single time point by Mann-Whitney's $U$-test, $p<0.05$. Error bars are shown in one direction only to enhance visualization.

\section{Hypotension}

As intended, MAP was reduced to $50-60 \mathrm{mmHg}$ both following caval obstruction of venous flow and in response to withdrawal of blood in both the TEA and placebo groups (Figure 1; Table 1). There was no significant difference in fluid administration between the two groups of pigs $(p=0.10)$ and urine output $(p=0.10)$ was similar. However, more blood was needed to be drawn in the 


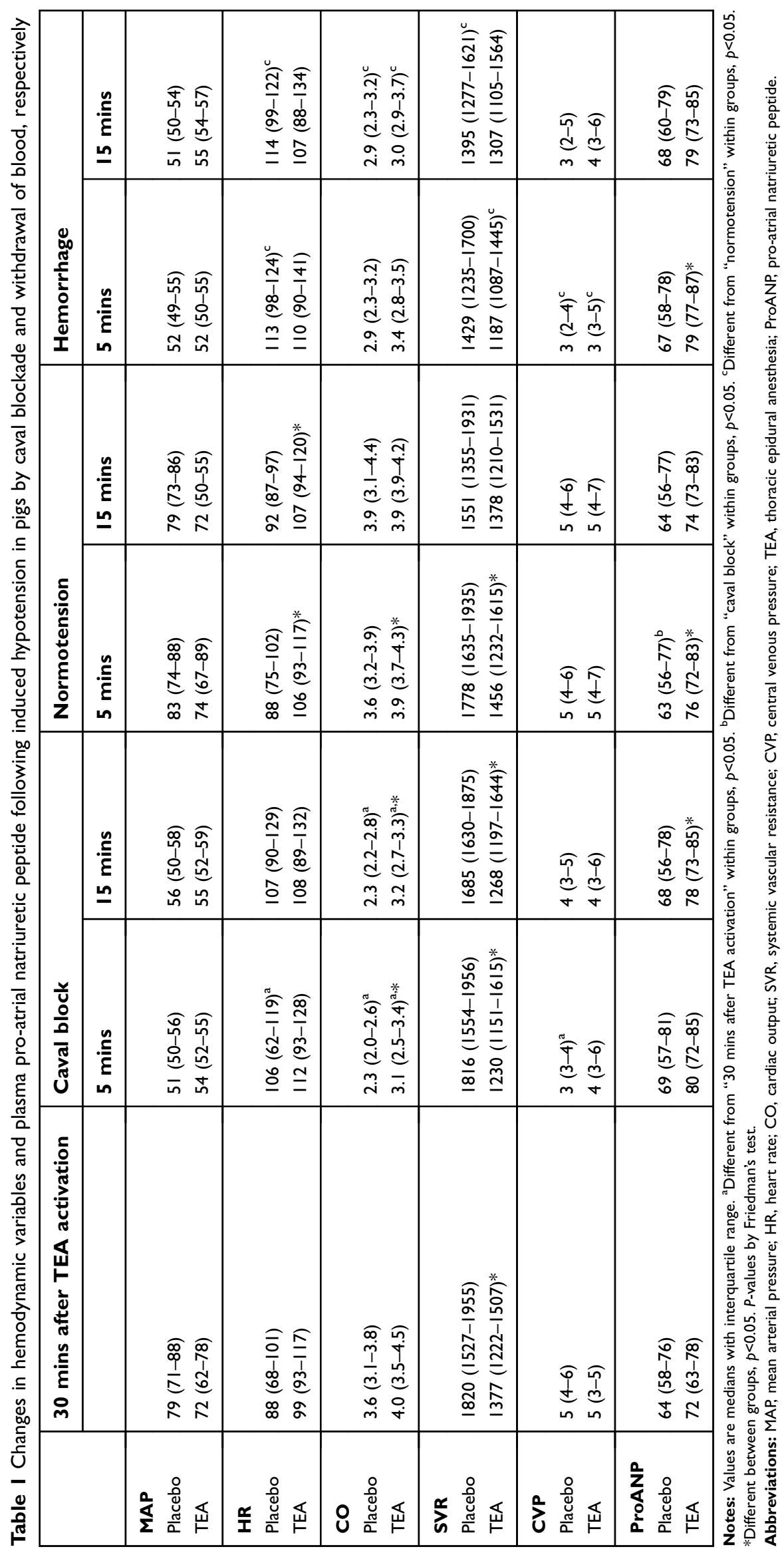


Table 2 Fluid input and output

\begin{tabular}{|l|l|l|l|}
\hline Fluid input and output & TEA & Placebo & p-value \\
\hline Electrolytes, $\mathbf{m L}$ & $1600(1475-1700)$ & $1500(1400-1525)$ & 0.10 \\
Urine output, $\mathbf{m L}$ & $300(250-350)$ & $400(288-500)$ & 0.10 \\
Withdrawal of blood, $\mathbf{m L}$ & $275(230-365)$ & $602(423-740)$ & 0.03 \\
\hline
\end{tabular}

Notes: Fluid input and output for pigs provided with thoracic epidural anesthesia (TEA) or saline (placebo) in the epidural space. Values are medians with interquartile range. $P$-values by Mann-Whitney's U- test.

placebo group to attain the targeted MAP (602 [423-740] [placebo] vs $275 \mathrm{~mL}$ [230-365] [TEA], $p=0.03$ ) (Table 2) corresponding to $18 \%(11-22)$ and $8 \%(7-12)$ of the estimated blood volume, respectively.

In the placebo group, obstruction of caval flow reduced CO and CVP (both $p<0.01)$ while HR increased $(p=0.04)$ with a stable SVR ( $p=0.37$ ) (Figure 1; Table 1). With TEA, $\mathrm{CO}$ decreased similarly, however, to a lesser extent than in the placebo group $(-19 \%$ vs $-38 \%, p<0.01)$, while CVP was unchanged $(p=0.81)$. Also, SVR did not decrease further in response to caval obstruction $(p=0.88)$ but remained reduced after activation of TEA, ie SVR was lower than in the placebo group $(p<0.01)$. Likewise, HR remained elevated and did not change further $(p=0.33)$. Deflation of the caval balloon normalized the hemodynamic variables in both groups, yet, HR remained elevated in the TEA group and was, therefore, higher than in the placebo group ( $p=0.03$ ).

In response to the withdrawal of blood $\mathrm{CO}(p<0.01)$, CVP $(p<0.01)$ and SVR $(p=0.01)$ decreased in the placebo group while HR increased $(p=0.02)$. With TEA, CO $(p=0.02)$ decreased similarly to the placebo group $(-19 \%$ vs $-21 \%, p=0.15)$ and also CVP was reduced $(p=0.03)$. SVR decreased further $(p=0.04)$, and HR was unchanged and not different from the value obtained in the placebo group $(p=0.90)$. In both groups, $\mathrm{SvO}_{2}$ decreased during withdrawal of blood $(-13 \%, p=0.04$ [placebo], $-16 \%$, $p=0.02$ [TEA]).

\section{Plasma proANP}

In the placebo group, plasma proANP tended to increase during caval obstruction of venous flow (64 [58-76] to 69 $\mathrm{pmol} / \mathrm{L}$ [57-81], $p=0.06$ ) and decreased toward baseline when the caval balloon was deflated and MAP normalized $(p=0.01)$ (Figure 1; Table 1). After the withdrawal of blood, plasma proANP did not change in the placebo group (64 [56-77] to $67 \mathrm{pmol} / \mathrm{L}$ [58-78], $p=0.15$ ). With TEA, plasma proANP was stable during both caval obstruction (72 [63-78] to $80 \mathrm{pmol} / \mathrm{L}$ [72-85], $p=0.09$ ) and withdrawal of blood (74 [73-83] to $79 \mathrm{pmol} / \mathrm{L}$ [7787], $p=0.07$ ). Yet, plasma proANP was elevated in the TEA group compared with the placebo group 15 mins after caval blockade $(p=0.03)$, when blood pressure was re-established after deflation of the caval balloon $(p=0.03)$ and during withdrawal of blood $(p=0.03)$.

\section{Discussion}

Considering the apparent relation between plasma ANP and $\mathrm{CBV},{ }^{9,11,12}$ a decrease in plasma proANP was expected when venous flow to the heart was limited by caval obstruction or hemorrhage, and even more so under the influence of TEA. Yet, plasma proANP was stable in the TEA group in response to both episodes of hypotensive hypovolemia and even tended to increase in the placebo group during caval obstruction.

The hemodynamic response to activation of TEA in pigs (a decrease in SVR and MAP) is consistent with reports in humans ${ }^{2,25}$ and was absent in the placebo group. Also, in these pigs, SVR remained lower than in the placebo group during caval obstruction and after normotension was re-established illustrating that TEA elicited depression of vasoconstrictor drive. The higher plasma proANP in the TEA group as compared with the placebo group may have added to this vasodilatory response due to the vasorelaxant effect of the hormone. ${ }^{26}$ Likewise, to reach the target MAP during withdrawal of blood, a smaller amount was needed to be withdrawn in the TEA group compared with the placebo group (about $8 \%$ vs $18 \%$ of the estimated blood volume). The difference in the amount of blood needed to reach the targeted MAP likely represents a loss of vasomotor tone to splanchnic vessels due to inhibition of sympathetic influence and therefore impaired cardiovascular tolerance to compensate for a blood loss by vasoconstriction. ${ }^{27,28}$

A decrease by $20 \%$ in CO was observed in the TEA group following caval obstruction as was also the case during withdrawal of blood along with a decrease in CVP and $\mathrm{SvO}_{2}$ supporting that cardiac preload was 
affected. ${ }^{29}$ Yet, plasma proANP was unchanged, and higher plasma levels were observed during caval blockade and withdrawal of blood as compared with the placebo group. Similar hemodynamic and proANP responses as measured in the TEA group was established in the placebo group during hypotensive hypovolemia. However, despite CO was more reduced (by 38\%) as compared with the TEA group (by 20\%) during caval obstruction, plasma proANP tended to increase. Thus, despite cardiac performance being impaired in response to hypotensive hypovolemia as indicated by its filling pressure (CVP), output (CO), and systemic oxygenation $\left(\mathrm{SvO}_{2}\right)$, plasma proANP was stable with or without the addition of TEA. Thus, the results indicate that secretion of ANP does not depend only on deviations in CBV.

The plasma ANP response to hemorrhage is reported by others with varying results. During prolonged exsanguination of anesthetized rats, N-terminal-proANP increased at a $\mathrm{MAP} \leq 50 \mathrm{mmHg}$, while it decreased during non-hypotensive hypovolemia (MAP > $100 \mathrm{mmHg}$ ) ${ }^{30}$ Similarly, plasma ANP is reported to increase in pigs exposed to hemorrhage to a MAP of about $50 \mathrm{mmHg} .{ }^{31}$ On the other hand, plasma ANP decreased or remained unchanged in rabbits, ${ }^{32}$ sheep, ${ }^{33,34}$ $\operatorname{dogs},{ }^{35}$ and rats $^{36,37}$ when bled to a MAP between 62 and $75 \mathrm{mmHg}$ (Table 3). Also, in healthy humans, plasma ANP was unchanged following the withdrawal of up to a $1,000 \mathrm{~mL}$ of blood at a stable systolic blood pressure. ${ }^{38}$ Taken together, it seems that hypotensive hypovolemia to a moderate extent reduces or maintains plasma ANP and proANP, but that hypotensive hypovolemia to a marked degree provokes a "paradoxical" increase.

Discrepancies in results could relate to the use of different animal species and the experimental setup as the duration and the extent of the blood withdrawal vary. Also, these findings may at least in part be explained by altered plasma clearance of ANP during hypotension. ${ }^{39}$ ANP is primarily eliminated in the pulmonary, splanchnic/hepatic, and renal circulations. ${ }^{40}$ Clearance of ANP is reduced when perfusion pressure to these organs is compromised, and elevated plasma ANP is observed in patients with liver cirrhosis and renal failure. ${ }^{41}$ Accordingly, plasma clearance of proANP may have been affected by impaired peripheral perfusion when MAP was reduced to $50-60 \mathrm{mmHg}$.

Table 3 Reported changes in plasma ANP and blood pressure in response to withdrawal of blood

\begin{tabular}{|c|c|c|c|c|c|}
\hline Study & Species & Intervention & $\begin{array}{l}\text { Change in MAP/SBP } \\
\text { during the } \\
\text { intervention }\end{array}$ & $\begin{array}{l}\text { Measured } \\
\text { ANP } \\
\text { fragment }\end{array}$ & $\begin{array}{l}\text { Change in plasma ANP } \\
\text { during the intervention }\end{array}$ \\
\hline Garcia et $\mathbf{a l} \mathbf{~}^{37}$ & Rat & $\begin{array}{l}\text { Blood withdrawal of } \\
10 \% \text { decrements }\end{array}$ & I I0-70 mmHg (SBP) & iANP & I3-8 pmol/ $\mathrm{L}^{\mathrm{a}}$ \\
\hline Hodsman et $\mathrm{al}^{38}$ & $\begin{array}{l}\text { Healthy } \\
\text { humans }\end{array}$ & $\begin{array}{l}\text { Withdrawal of } 500- \\
\mathrm{I}, 000 \mathrm{~mL} \text { blood }\end{array}$ & Not specified & $\alpha$-hANP & $\begin{array}{l}\text { Not specified, but "no change" } \\
\text { reported }\end{array}$ \\
\hline Leskinen et $\mathbf{a l}^{30}$ & Rat & $\begin{array}{l}\text { Blood withdrawal of } \\
1.5 \mathrm{~mL} \text { decrements }\end{array}$ & $\begin{array}{l}\text { Anesthetized rats: 100-35 } \\
\text { mmHg (MAP) } \\
\text { Conscious rats: } 120-100 \\
\text { mmHg (MAP) }\end{array}$ & NT-ProANP & $\begin{array}{l}\text { Anesthetized rats: } 500-700 \\
\mathrm{pmol} / \mathrm{L}^{\mathrm{a}} \\
\text { Conscious rats: } 1,500-1,000 \\
\mathrm{pmol} / \mathrm{L}^{\mathrm{a}}\end{array}$ \\
\hline Shackford et $\mathrm{al}^{31}$ & Pig & $\begin{array}{l}\text { Withdrawal of } 40 \% \text { of } \\
\text { the blood volume }\end{array}$ & $106-53 \mathrm{mmHg}$ (MAP) & iANP & $\mathrm{I}, \mathrm{I} 38-\mathrm{I}, 505 \mathrm{pmol} / \mathrm{mL}^{*}$, a \\
\hline Courneya et al $^{32}$ & Rabbit & $\begin{array}{l}\text { Blood withdrawal of } \\
10 \% \text { decrements }\end{array}$ & 107-75 mmHg (MAP) & iANP & $220-184 \mathrm{pmol} / \mathrm{L}^{*}$, a \\
\hline Yoshida et $\mathrm{al}^{36}$ & Rat & $\begin{array}{l}\text { Blood withdrawal up } \\
\text { to } 2 \% \text { of body weight }\end{array}$ & II8-62 mmHg (MAP) & $\alpha$-hANP & $786-5 / 8 \mathrm{pmol} / \mathrm{L}^{*}$ a \\
\hline Yates et $\mathbf{a l}^{33}$ & Sheep & $\begin{array}{l}\text { Blood withdrawal of } \\
25 \% \text { of blood volume }\end{array}$ & 72-62 mmHg (MAP) & ANP (99-126) & I76-I40 pmol/L*b \\
\hline Levy et $\mathbf{a l}^{35}$ & Dog & $\begin{array}{l}\text { Blood withdrawal of } \\
30 \% \text { of blood volume }\end{array}$ & $125-78 \mathrm{mmHg}(\mathrm{SBP})$ & iANP & I47-125 pmol/L*, b \\
\hline Cameron et $\mathrm{al}^{34}$ & Sheep & $\begin{array}{l}\text { Blood withdrawal of } \\
15 \mathrm{~mL} / \mathrm{kg}\end{array}$ & $88-70 \mathrm{mmHg}(\mathrm{MAP})$ & iANP & $800-810 \mathrm{pmol} / \mathrm{L}^{\mathrm{b}}$ \\
\hline
\end{tabular}

Notes: ${ }^{a} p<0.05,{ }^{b} p>0.05$, *converted values from $p g / m L$.

Abbreviations: MAP, mean arterial pressure; SBP, systolic blood pressure; ANP, atrial natriuretic peptide; iANP, immunoreactive ANP; $\alpha$-hANP, alfa-human ANP; NTProANP, N-terminal proANP. 
Alternative explanations for a stable plasma proANP in response to hypotensive central hypovolemia should be considered. We speculate that a marked reduction in CBV could imply that the walls of the atrium meet and release ANP or that ANP is released by deformation of the atrial wall. An evaluation of the atrium by, eg, MRI could reveal the deformation of the atrial walls during hypotensive central hypovolemia. In both patients with congestive heart failure and healthy humans, plasma ANP correlates to MRI-determined right atrial volume $(r=0.91, p<0.001)$ but the association has not been examined during hypotensive hypovolemia. ${ }^{6}$

The strengths of the study include the randomized blinded design and that a correct position of the thoracic epidural catheter was verified by $\mathrm{x}$-ray. Thus, two animals were excluded due to incorrect placement of the catheter. A determination of plasma brain-natriuretic peptide (BNP) was not included for evaluating CBV because BNP seems, in contrast to ANP,,${ }^{9,12,42}$ to be a poor marker of acute changes in $\mathrm{CBV}^{43}$ On the other hand, BNP is a sensitive marker for predicting heart failure ${ }^{44}$ and cardiac events after non-cardiac surgery. ${ }^{45}$

\section{Conclusion}

Plasma proANP was stable in response to relative or hemorrhage-induced hypovolemia to a MAP of 50-60 $\mathrm{mmHg}$, and the response was independent of TEA activation. Thus, plasma proANP does not follow deviations in $\mathrm{CBV}$ in pigs during hypotensive hypovolemia.

\section{Ethics approval and informed consent}

The study was approved by the local Animal Experiments Inspectorate (protocol number 2014-15-0201-00385 approved on October 30,2014) in accordance with the national and the European Union legislation.

\section{Data sharing statement}

The data are available from the corresponding author on reasonable request.

\section{Acknowledgments}

For laboratory supervision, the authors thank Anne Truesen Asanovski, Laboratory Technician, Department of Clinical Biochemistry, Rigshospitalet, Copenhagen, Denmark. For study funding, the authors thank Lundbeck
Fonden, Ehrenreich's Fond, Gangstedfonden, and J.E. Ormstrup and G. Ormstrup's Fond.

\section{Disclosure}

Dr Rune B Strandby reports grants from Lundbeck Fonden (R230-2016-2727), Ehrenreich's Fond, Gangstedfonden (A31738), Civil Engineer J. E. and G. Ormstrup's Fond, during the conduct of the study. The authors report no other conflicts of interest in this work.

\section{References}

1. Jenstrup M, Ejlersen E, Mogensen T, Secher NH. A maximal central venous oxygen saturation ( $\mathrm{SvO} 2 \mathrm{max})$ for the surgical patient. Acta Anaesthesiol Scand Suppl. 1995;107:29-32.

2. Michelet P, Roch A, D'Journo XB, et al. Effect of thoracic epidural analgesia on gastric blood flow after oesophagectomy. Acta Anaesthesiol Scand. 2007;51(5):587-594. doi:10.1111/j.13996576.2007.01290.x

3. Magder SA. The highs and lows of blood pressure: toward meaningful clinical targets in patients with shock. Crit Care Med. 2014;42 (5):1241-1251. doi:10.1097/CCM.0000000000000324

4. Lakhal K, Ehrmann S, Perrotin D, Wolff M, Boulain T. Fluid challenge: tracking changes in cardiac output with blood pressure monitoring (invasive or non-invasive). Intensive Care Med. 2013;39 (11):1953-1962. doi:10.1007/s00134-013-3086-6

5. Edwards BS, Zimmerman RS, Schwab TR, Heublein DM, Burnett JC Jr. Atrial stretch, not pressure, is the principal determinant controlling the acute release of atrial natriuretic factor. Circ Res. 1988;62 (2):191-195.

6. Globits S, Frank H, Pacher B, et al. Atrial natriuretic peptide release is more dependent on atrial filling volume than on filling pressure in chronic congestive heart failure. Am Heart J. 1998;135 (4):592-597.

7. Levin ER, Gardner DG, Samson WK. Natriuretic peptides. $N$ Engl $J$ Med. 1998;339(5):321-328. doi:10.1056/NEJM199807303390507

8. Kasama S, Furuya M, Toyama T, Ichikawa S, Kurabayashi M. Effect of atrial natriuretic peptide on left ventricular remodelling in patients with acute myocardial infarction. Eur Heart J. 2008;29(12):14851494. doi:10.1093/eurheartj/ehn206

9. Vogelsang TW, Marving J, Crandall CG, et al. Atrial natriuretic peptide and acute changes in central blood volume by hyperthermia in healthy humans. Open Neuroendocrinol $J$. 2012;5:1-4. doi: $10.2174 / 1876528901205010001$

10. Heintz B, Konigs F, Dakshinamurty KV, et al. Response of vasoactive substances to intermittent ultrafiltration in normotensive hemodialysis patients. Nephron. 1993;65(2):266-272. doi:10.1159/000187486

11. Hanel B, Teunissen I, Rabol A, Warberg J, Secher NH. Restricted postexercise pulmonary diffusion capacity and central blood volume depletion. J Appl Physiol (1985). 1997;83(1):11-17. doi:10.1152/ jappl.1997.83.1.11

12. Matzen S, Knigge U, Schutten HJ, Warberg J, Secher NH. Atrial natriuretic peptide during head-up tilt induced hypovolaemic shock in man. Acta Physiol Scand. 1990;140(2):161-166. doi:10.1111/j.17481716.1990.tb08987.x

13. Legault L, van Nguyen P, Holliwell DL, Leenen FH. Hemodynamic and plasma atrial natriuretic factor responses to cardiac volume loading in young versus older normotensive humans. Can J Physiol Pharmacol. 1992;70(12):1549-1554.

14. Ray CA, Delp MD, Hartle DK. Interactive effect of body posture on exercise-induced atrial natriuretic peptide release. Am J Physiol. 1990;258(5 Pt 1):E775-E779. 
15. Cai Y, Holm S, Jenstrup M, et al. Electrical admittance for filling of the heart during lower body negative pressure in humans. J Appl Physiol (1985). 2000;89(4):1569-1576. doi:10.1152/jappl.2000.89.4.1569

16. Strandby RB, Ambrus R, Secher NH, et al. Plasma pro-atrial natriuretic peptide to estimate fluid balance during open and robot-assisted esophagectomy: a prospective observational study. BMC Anesthesiol. 2017;17(1):20. doi:10.1186/s12871-017-0314-6

17. Rasmussen KC, Hojskov M, Ruhnau B, et al. Plasma pro-atrial natriuretic peptide to indicate fluid balance during cystectomy: a prospective observational study. BMJ Open. 2016;6:e010323. doi:10.1136/bmjopen-2015-010323

18. Schwarte LA, Picker O, Hohne C, Fournell A, Scheeren TW. Effects of thoracic epidural anaesthesia on microvascular gastric mucosal oxygenation in physiological and compromised circulatory conditions in dogs. $\mathrm{BrJ}$ Anaesth. 2004;93(4):552-559. doi:10.1093/bja/aeh235

19. Moustgaard J, Hyldgaard-Jensen J, Paludan B. Fysiologi Og Biokemi for Veterincerstuderende (In Danish). Copenhagen: KF Mortensen; 1983:416.

20. Morgenthaler NG, Struck J, Thomas B, Bergmann A. Immunoluminometric assay for the midregion of pro-atrial natriuretic peptide in human plasma. Clin Chem. 2004;50(1):234-236. doi:10.1373/clinchem.2003.021204

21. Buckley MG, Marcus NJ, Yacoub MH. Cardiac peptide stability, aprotinin and room temperature: importance for assessing cardiac function in clinical practice. Clin Sci (Lond). 1999;97(6):689-695.

22. Goetze JP, Hansen LH, Terzic D, et al. Atrial natriuretic peptides in plasma. Clin Chim Acta. 2015;443:25-28. doi:10.1016/j.cca.2014.08.017

23. Morgenthaler NG, Struck J, Christ-Crain M, Bergmann A, Muller B. Pro-atrial natriuretic peptide is a prognostic marker in sepsis, similar to the APACHE II score: an observational study. Crit Care. 2005;9 (1):37-45. doi:10.1186/cc2951

24. Hunter I, Rehfeld JF, Goetze JP. Measurement of the total proANP product in mammals by processing independent analysis. $J$ Immunol Methods. 2011;370(1-2):104-110. doi:10.1016/j.jim.2011.06.005

25. Hachenberg T, Holst D, Ebel C, et al. Effect of thoracic epidural anaesthesia on ventilation-perfusion distribution and intrathoracic blood volume before and after induction of general anaesthesia Acta Anaesthesiol Scand. 1997;41(9):1142-1148.

26. Schultz HD, Gardner DG, Deschepper CF, Coleridge HM, Coleridge JC. Vagal C-fiber blockade abolishes sympathetic inhibition by atrial natriuretic factor. Am J Physiol. 1988;255(1 Pt 2):6-13.

27. Hogan QH, Stekiel TA, Stadnicka A, Bosnjak ZJ, Kampine JP. Region of epidural blockade determines sympathetic and mesenteric capacitance effects in rabbits. Anesthesiology. 1995;83(3):604-610.

28. Arndt JO, Hock A, Stanton-Hicks M, Stuhmeier KD. Peridural anesthesia and the distribution of blood in supine humans. Anesthesiology. 1985;63(6):616-623.

29. Perner A, Haase N, Wiis J, White JO, Delaney A. Central venous oxygen saturation for the diagnosis of low cardiac output in septic shock patients. Acta Anaesthesiol Scand. 2010;54(1):98-102. doi:10.1111/j.1399-6576.2009.02086.x

30. Leskinen H, Ruskoaho H, Huttunen P, Leppaluoto J, Vuolteenaho O. Hemorrhage effects on plasma ANP, NH2-terminal pro-ANP, and pressor hormones in anesthetized and conscious rats. Am J Physiol. 1994;266(6 Pt 2):1933-1943.
31. Shackford SR, Norton CH, Ziegler MG, Wilner KD. The effect of hemorrhage and resuscitation on serum levels of immunoreactive atrial natriuretic factor. Ann Surg. 1988;207(2):195-200. doi:10.1097/00000658-198802000-00014

32. Courneya CA, Wilson N, Ledsome JR. Plasma vasopressin and atrial natriuretic factor in response to blood volume changes in the anaesthetized rabbit. Can J Physiol Pharmacol. 1989;67(4):344-352.

33. Yates NA, Parkes DG, Coghlan JP, Scoggins BA, McDougall JG. The effect of hypovolemia on the renal and cardiovascular responses to atrial natriuretic factor (ANF) infusion. Life Sci. 1992;50(24):19051912

34. Cameron VA, Espiner EA, Nicholls MG, Skidmore DS. Hormone and hemodynamic responses to atrial natriuretic peptide in conscious sheep and effect of hemorrhage. Endocrinology. 1988;122(2):407414. doi:10.1210/endo-122-2-407

35. Levy M, Cernacek P. Response to atrial natriuretic peptide in dogs with hypovolemic acute pancreatitis. Am J Physiol. 1989;256(2 Pt 2):211-217.

36. Yoshida K, Kawano Y, Hirata Y, et al. Regulation of plasma atrial natriuretic peptide and the cardiopulmonary baroreflex in the rat. Jpn Circ J. 1987;51(11):1310-1314.

37. Garcia R, Cantin M, Thibault G. Role of right and left atria in natriuresis and atrial natriuretic factor release during blood volume changes in the conscious rat. Circ Res. 1987;61(1):99-106.

38. Hodsman GP, Phillips PA, Ogawa K, Johnston CI. Atrial natriuretic factor in normal man: effects of tilt, posture, exercise and haemorrhage. J Hypertens Suppl. 1986;4(6):503-505.

39. Tan AC, Russel FG, Thien T, Benraad TJ. Atrial natriuretic peptide. An overview of clinical pharmacology and pharmacokinetics. Clin Pharmacokinet. 1993;24(1):28-45. doi:10.2165/00003088199324010-00003

40. Hollister AS, Rodeheffer RJ, White FJ, et al. Clearance of atrial natriuretic factor by lung, liver, and kidney in human subjects and the dog. J Clin Invest. 1989;83(2):623-628. doi:10.1172/JCI113926

41. Morgan TR, Imada T, Hollister AS, Inagami T. Plasma human atrial natriuretic factor in cirrhosis and ascites with and without functional renal failure. Gastroenterology. 1988;95(6):1641-1647. doi:10.1016/ S0016-5085(88)80090-8

42. Vogelsang TW, Yoshiga CC, Hojgaard M, et al. The plasma atrial natriuretic peptide response to arm and leg exercise in humans: effect of posture. Exp Physiol. 2006;91(4):765-771. doi:10.1113/ expphysiol.2006.033357

43. James KB, Troughton RW, Feldschuh J, et al. Blood volume and brain natriuretic peptide in congestive heart failure: a pilot study. $\mathrm{Am}$ Heart J. 2005;150(5):984. doi:10.1016/j.ahj.2005.07.031

44. Wright SP, Doughty RN, Pearl A, et al. Plasma amino-terminal probrain natriuretic peptide and accuracy of heart-failure diagnosis in primary care: a randomized, controlled trial. J Am Coll Cardiol. 2003;42(10):1793-1800.

45. Ryding AD, Kumar S, Worthington AM, Burgess D. Prognostic value of brain natriuretic peptide in noncardiac surgery: a metaanalysis. Anesthesiology. 2009;111(2):311-319. doi:10.1097/ ALN.0b013e3181aaeb11
Local and Regional Anesthesia

\section{Publish your work in this journal}

Local and Regional Anesthesia is an international, peer-reviewed, open access journal publishing on the development, pharmacology, delivery and targeting and clinical use of local and regional anesthetics and analgesics. The journal welcomes submitted papers covering original research, basic science, clinical studies, reviews \& evaluations, guidelines, expert opinion and commentary, case reports and extended reports. The manuscript management system is completely online and includes a very quick and fair peer-review system, which is all easy to use. Visit http://www.dovepress.com/testimonials. php to read real quotes from published authors. 